Acta medico-historica Rigensia (2016) X:138-155

DOI: 10.25143/amhr.2016.X.07

Valdis Pīrāgs

\title{
Latvijas internās medicīnas skola kā ideju pēctecības modelis ${ }^{1}$
}

\author{
Zināšanas ir galīgas, bet mūsu \\ nezināšana jeb ignorance ir bezgalīga.
}

KĀRLIS POPERS

Pārrāvums ideju pēctecībā ir viena no mūsdienu pasaules pamatproblēmām. Ievada vietā vēlos pastāstīt par savām pārdomām, kas radās kādās saviesīgās vakariņās, sēžot pie viena galda ar dažādu Eiropas valstu pārstāvjiem. Sarunas ievirzījās par Eiropas, un ne tikai Eiropas, ekonomiskās krīzes cēloṇiem. Itāliešu viedoklis bija, ka Eiropa ir zaudējusi savu kultūru un noķ̣uvusi neizglītotu barbaru politiķu un biznesmeņu rokās, bet angḷi un vācieši iebilda, ka nevis kultūras zudums, bet gan pārmērīgs savtīgums un turīgo cilvēku vēlēšanās ar dažādiem juridiskiem trikiem izvairīties no nodokḷu maksāšanas un pārmērīga uzticēšanās baņķieru solījumiem iegūt naudu bez reāla darba ir visu ekonomisko nelaimju pamatā. Tam visam var pilnīgi piekrist, paveroties uz Latvijas saimniecības un pārvaldes satricinājumiem 2008.-2010. gada krīzes laikā. Lai arī ekonomika atkal ir stabilizējusies, vai mēs esam atguvuši savu tradicionālo kultūru, vai cilvēki atkal ir gatavi neatlaidīgi pūlēties, lai ar sava produktīvā darba, nevis piesavināšanās un blēdīšanās, palīdzību celtu savu materiālās un garīgās labklājības līmeni? Katrā ziṇā uz tagadējo Dienvideiropas valstu satricinājumu fona piln̄̄gi noteikti Latvija ir atguvusi veiksmīgas valsts veidolu, bet vai tās iedzīvotāji ir atguvuši pašcieņu un lokālās piederības sajūtu, kas ir tik ārkārtīgi nepieciešama

${ }^{1}$ V. Pīrāga lekcija, 2012. gadā saņemot P. Stradiņa balvu. 
ilgtermiņa stabilai izaugsmei? Vai ar̄̄ mēs vēl arvien dzīvojam melīgi kultivētās mentalitātes varā, ka esam pēc 700 gadu verdzības brīvlaisto dzimtcilvēku pēcteči, kas nekad nav īsti spējuši tikt galā ar savu brīvību? Vai varbūt ticam, ka esam pēc 50 gadu okupācijas nesen brīvlaistie padomju cilvēki un viņu pēcteči? Vai no š̄i uzskata gluži saprotami izriet, ka labā dzīve meklējama Anglijā, Vācijā, Zviedrijā vai varbūt Krievijā un Amerikā, pēc iespējas ātrāk atsakoties no savas identitātes? Bet varbūt tomēr patiesība ir citādāka, un ir pienācis laiks atcerēties lietas, par kurām mēs parasti domājam, ka mēs tās nezinām?

\title{
Viduslaiku medicīnas tradīcijas Latvijā
}

\author{
Ir lietas, par kurām mēs zinām, ka mēs tās zinām. \\ Ir lietas, par kurām mēs zinām, ka mēs tās \\ nezinām. Bet ir arī lietas, par kurām mēs \\ nezinām, ka mēs tās nezinām. \\ DONALDS RAMSFELDS (2002)
}

Kurzemes dziedniekus pieminējis Brēmenes Ādams savā ap 1080. gadu rakstītās hronikas "Hamburgas baznīcas bīskapu darbi" fragmentā par kuršiem: "Visas viņu mājas ir pilnas ar priesteriem, pareǵiem un burvjiem, kuri pat tērpjas mūku apǵērbā. No visas pasaules tur nāk prasīt atbildes, visvairāk no Spānijas un Grieksijas.”2

Par pirmo Livonijas ārstu viduslaiku Eiropas izpratnē var uzskatīt cisterciešu ordeņa mūku Teoderiku (frater Theodericus Cisterciensis, ap 1150.-1219. gadu), kas Latviešu Indriķa hronikā pirmo reizi pieminēts, stāstot par 1190. gada notikumiem. Vinsš esot nodarbojies ne tikai ar kristīgo misionārismu Turaidas līvu zemē, bet arī ar vietējo iedzīvotāju dziedināšanu. Uzskata, ka viņa pacients bija līvu dižciltīgais Kaupo, kas izveseļošanās gadījumā solīja pāriet katoḷu ticībā un vēlāk kopā ar viṇu devās uz Romu pie pāvesta. Hronikas tekstā lasāms, ka "kāds ievainots

2 Divinis, auguribus atque nigromanticis omnes domus plenae sunt, qui etiam vestitu monachico induti sunt. A toto orbe ibi responsa petuntur, maxime ab Hispanis et Graecis. Adamus Bremensis. Gesta Hammaburgensis Ecclesiae Pontificum // In: Werner Trillmich, Rudolf Buchner (Hrsg.): Quellen des 9. und 11. Jahrhunderts zur Geschichte der Hamburgischen Kirche und des Reiches. 7. Auflage. - Darmstadt, 2000. 
Turaidas līvs lūdza brāli Teoderiku, lai tas viņu izdziedinot, un apsolīja kristīties, ja tikšot izdziedināts. Brālis sagrūda zāles, gan nezinādams to iedarbību, bet, piesaucis tā Kunga vārdu, viņu kristīdams izārstēja gan miesā, gan dvēselē. Un šis Turaidā bija pirmais, kas pieņēma Kristus ticību."3 Kad līvi mūku Teoderiku gribēja ziedot saviem dieviem, viņš brīnumainā veidā izglābies, jo pēc līvu ticējumiem veiktajā zīlēšanas rituālā likteņa zirgs trīs reizes pāri uz zemes noliktajam šksēpam spēra labo kāju. Zīmīgi, ka klātesošais līvu gaišreǵis pret to iebilda, sakot, ka zirga mugurā sēžot kristiešu dievs un virzot tam kāju, kura liekama pirmā. Iespējams, ka tā ir pirmā norāde uz ārstu savstarpējo konkurenci jau tajā laikā. Šis sižets ir plašāk pazīstams pēc latviešu gleznotāja Artūra Baumaņa (1867-1904) gleznas "Likteņa zirgs".

Izidors Brensons savu lielisko biogrāfisko enciklopēdiju "Vidzemes ārsti no senākajiem laikiem līdz mūsdienām"4 un "Kurzemes ārsti no hercogu laiku sākuma līdz mūsdienām"5 ievada daḷās rakstīja, ka senajā Livonijā, tāpat kā vācu zemēs, ar dziedniecību nodarbojās četru profesiju pārstāvji - pirtnieki, bārddziņi, celsojošie ārsti un akadēmiski izglītotie ārsti, bet tikai ceturtie drīkstēja ārstēt iekšks̄īgās slimības. No akadēmiski izglītotajiem ārstiem Brensons kā pirmo pieminēja Livonijas ordeņa mestra Zigfrīda Landera fon Špānheima ārstu Johanu Kercebroku, kas viņu pavadījis karagājienos no 1415. līdz 1424. gadam. Livonijas provinces koncils Rīgā 1424. gadā nolēma, ka ar ārstēšanu drīkst nodarboties visi garīdznieki, izṇemot bīskapus, arhidiakonus un abatus. Zināms, ka Rīgas domkungs Johaness no Ozenbrigenas (Osenbrüggen) no 1426. līdz 1454. gadam ārstējis vairākus ordeņa mestrus. Ārstniecībai izmantoja klosteru dārzos augošās salvijas, piparmētras, baldriānu, pētersīḷus un citus augus. Līdztekus viņiem praktizējusi daudzskaitlīga latviešu tautas dziednieku kārta. Pēc baznīcas reformācijas 16. gadsimtā luterāṇu garīdznieki ar ārstēšanu vairs nenodarbojās, toties nikni cīnījas pret latviešu

3 Indriķa hronika. No latīṇu valodas tulkojis Ā. Feldhūns; Ē. Mugurēviča priekšvārds un komentāri. - Rīga: Zinātne, 1993. - 51. lpp.

${ }^{4}$ Brennsohn I. Die Aerzte Livlands von den ältesten Zeiten bis zur Gegenwart ein biographisches Lexikon; nebst einer Einleitung über das Medizinalwesen Livlands. - Mitau, 1905.

5 Brennsohn I. Die Ärzte Kurlands vom Beginn der herzoglichen Zeit bis zur Gegenwart ein biographisches Lexikon; nebst einer historischen Einleitung über das Medizinalwesen Kurlands. 2 Ausgabe. - Riga, 1929. 
māņticību un burvjiem un raganām (proti, tautas dziedniekiem). Vajātie tautas dziednieki ātri ieņēma padzîto mūku vietu, viņu padomus uzklausīja arī nomaļajās muižās dzīvojošie kungi un viņu sievas. Pēc Brensona rakstītā var secināt, ka vēl 19. gadsimtā Baltijas provinču augstdzimušo kungu sievas esot bijušas plaši pazīstamas kā prasmīgas dzemdību palīdzes ${ }^{6}$. Tātad Latvijas viduslaiku mūku ordeņu klosteru dziedniecība kopš 13. gadsimta mijiedarbojās ar latviešu tautas medicīnu. Tautas dziedniecības tradīcijas un holistiskais pasaules uzskats arī vēlāk ietekmējis muižās dzīvojošo vācbaltiešu kungu mentalitāti.

Pēc mūku ordeṇu padzīšanas no Rīgas tajā nepārtraukti praktizējuši akadēmiski izglītoti ārsti. No Jana Kornārija (ap 1500-1558) un Zaharija Stopija (ap 1525-1603) līdz Nikolausam fon Himzelim (1729-1764), Oto fon Hūnam (1764-1832) un 1822. gadā dibinātajai Rīgas praktizējošo ārstu biedrībai neapšaubāmi izsekojama pēctecība un cieša saistība ar protestantisko vācu zemju universitāšu tradīcijām.

Kopīgā iezīme tajā laikā Latvijā strādājošo ārstu darbībā ir viņu orientēšanās uz klīnisko praksi un kazuistiku, ne uz zinātnisko pētniecību. Atkārtoti rakstīts, ka Rīgā strādājošie ārsti veikuši pirmo ētera narkozi Krievijas impērijā (1847) un pirmo uretrocistoskopiju (1862).

Vai viņi ir Latvijas medicīnas skolai piederīgi? Šo jautājumu jau iepriekš iztirzājuši vairāki autori, piemēram, Arnis V̄̄ksna ${ }^{7,8}$ un - zinātniskās skolas aspektā - Jānis Stradiņš. ${ }^{9}$ Vai Latvijas medicīnas skolai pieder Rīgā dzimušais vācbaltiešu ķirurgs un Tērbatas, Vircburgas un Berlīnes universitātes medicīnas profesors Ernsts fon Bergmanis (1836-1907) un viņa dēls internists un Marburgas, Frankfurtes, Berlīnes un Minhenes universitātes medicīnas profesors Gustavs fon Bergmanis (1878-1955)? Tradicionāli viņus uzskata par vācu universitāšu zinātniskajām skolām piederīgiem, turklāt Tērbatas universitāti bieži vien ietilpina šajā kultūras lokā.

6 Indriķa hronika. No latīṇu valodas tulkojis Ā. Feldhūns; E. Mugurēviča priekšvārds un komentāri. - Rīga: Zinātne, 1993.

7 Vīksna A. Medicīnas sākumi Latvijas novados. - Rīga: Rīgas Starptautiskais Medicīnas zinātnes un farmācijas centrs, 1993.

8 Vīksna A. Latgales ārsti un ārstniecīiba, 1772-1918. - Latvijas Universitāte, 2004.

9 Stradinsš J. Zinātnes un augstskolu sākotne Latvijā. - Rīga: Latvijas vēstures institūta apgāds, 2009. 


\title{
Nedaudz par Tērbatas universitātes ietekmi
}

\author{
Vairumam medicinisko teoriju to nepietiekamība \\ rodas tādēl, ka visas š̄is mācības, lai arī pašas par sevi \\ varbūt ir pareizas, tomēer nepietiekami pārzina \\ savu būtisko pamatu. \\ MĀRTIN̦Š ZīLE ${ }^{10}$
}

Par Tērbatas universitātes medicīnas skolu rakstījis Zviedrijā dzīvojošais igauṇu ārsts un vēsturnieks Ilo Kebins savā pamatīgajā darbā "Medicīniskā pētniecība un apmācība Tērbatas / Tartu universitātē (18021940): rezultāti un nozīmīgums medicīnas attīstībā". Pēc viņa uzskata, Tērbatas universitāte pildīja tilta lomu starp Krievijas impērijas galvaspilsētas Pēterburgas un vācu universitāšu intelektuāļiem. ${ }^{11}$

Šeit jāatgādina, ka 19. gadsimtā Tērbatas universitātē darbojās vairāki ar Baltijas guberņu latviešu daļu saistīti un starptautiski pazīstami mūsdienu akadēmiskās medicīnas pamatlicēji, no kuriem dạ̧a bija latviešu izcelsmes vai prata latviešu valodu, piemēram, anatomijas (no 1842. gada), fiziologijas un patologijas profesors (no 1843. gada) Frīdrihs Biders (1810-1894), viņa skolnieks prozektors un ārkārtas profesors (no 1858. gada) Kārlis Kupfers (1829-1902), fiziologijas profesors (no 1869. gada) Aleksandrs Šmits (1831-1894), farmakologijas un dietologíjas profesors (no 1869. gada) Osvalds Šmīdebergs (1839-1921).

Cik lielā mērā Latvijas medicīnas skolas tapšanu ietekmējušas Tērbatas universitātes fizioloǵijas un patologijas profesora (no 1821. gada), fizikas profesora (no 1826. gada) Frīdriha Parrota (1792-1841) idejas? Vai arī slavenā vācu internista Bernharda Naunīna (Naunyn, 1839-1925), kas bija klīniskās terapijas profesors (no 1869. gada), un psihiatra Emīla Krepelīna (1856-1926), kas bija psihiatrijas profesors (no 1885. gada), darbībai ir bijusi kāda paliekoša ietekme, piemēram, uz Mārtinu Zīli, kas Tērbatas universitātē no 1883. līdz 1888. gadam studēja medicīnu?

10 Mārtiņš Zīle, pārfrazējot Hermaņa Keizerlinga domu darbā "Was uns not tut. Was ich will" (1919).

11 Käbin I. Medizinische Forschung und Lehre an der Universität Dorpat / Tartu 1802-1940: Ergebnisse und Bedeutung für die Entwicklung der Medizin. Lüneberg: Nordostdeutsches Kulturwerk, 1986. 
Varbūt, ka jātver plašāk un jāpēta, vai arī Tērbatas universitātes filozofijas profesora (no 1849. gada) Ludviga Štrimpel̦a (Strümpell, 1812-1899) idejām ir bijusi ietekme ne tikai uz viņa dēlu Ādolfu Štrimpeli (1852-1925), kas ir viens no pirmajiem moderno psihoanalīzes ideju priekštečiem, ${ }^{12}$ bet arī uz Tērbatas universitātes latviešu studentiem?

Vai Tērbatas universitātes profesoru paustajām idejām bija ietekme uz Rīgā dzimušo slaveno filozofu Nikolaju Hartmani, kas studēja medicīnu Tērbatas universitātē no 1902. līdz 1903. gadam, pēc tam - filozofiju Pēterburgā? Jau būdams fỉlozofijas profesors Marburgas, Ķelnes, Berlīnes un Getingenes universitātē, viņš attīstīja oriǵinālu filozofijas virzienu par esamību, esamības kategorijām un izziņas kategorijām.

Vai tās ietekmēja biologu un filozofu Jakobu fon Ikšķilu (1864-1944), kurš no 1884. līdz 1889. gadam studēja zooloǵiju Tērbatas universitātē? Viṇa 1909. gadā izdotā grāmata "Dzīvnieku apkārtējā vide un iekšējā vide"13 tiek uzskatīta par vienu no biosemiotikas un ekologijas pirmsākumiem, kas ieviesa apkārtējās vides jēdzienu mūsdienu kultūrā.

Vai tās ietekmēja arī dabas zinātņu studentu Hermani Keizerlingu (1880-1946), kas Tērbatas universitātē studēja no 1898. līdz 1899. gadam, bet 1920. gadā Darmštatē (Vācijā) nodibināja Brīvās filozofijas biedrību un Gudrības skolu? ${ }^{14}$ Un galu galā, kādu iespaidu tās atstāja arī uz Juriju Lotmanu (1922-1993), kas Tartu universitātē ieradās 1954. gadā un strādāja par krievu literatūras pasniedzēju, bet vēlāk izveidojās par semiotiskās kultūras teorijas pamatlicēju (skaidro kultūru kā hierarhisku simbolu un zīmju sistēmu).

Jānis Stradiṇš savā darbā "Zinātnes un augstskolu sākotne Latvijā" secina, ka Tērbatas universitātes zinātnieki bija tiešie skolotāji vairākumam 19. gadsimta Latvijā strādājošo inteliǵentu un viņu ietekme varētu būt devusi impulsus dažādām ierosmēm, pārspējot vācu universitātes, kuru ietekme Latvijā bija noteicošā 17.-18. gs., kā arī Krievijas impērijas

12 Von Strumpell A. Ueber die Entstehung und die Heilung von Krankheiten durch Vorstellungen // Rede beim Antritt des Prorectorats der Königlich Bayerischen Friedrich-Alexanders-Universität Erlangen am 4. November 1892 gehalten, Erlangen, 1892.

13 Von Uexküll J. Umwelt und Innenwelt der Tiere. - Berlin: J. Springer, 1909.

14 Von Keyserling H. Schöpferische Erkenntnis: Einführung in die Schule der Weisheit. - Darmstadt: Reichl, 1922. 
universitātes. Liels skaits Tērbatas universitātes profesoru un izcilu absolventu nāca no Vidzemes latviešu daḷas vai Kurzemes un mūža gaitā kaut kādā mērā saglabāja saites ar dzimto pusi, īpaši pieminot Bergmaņu dzimtu no Rūjienas, Kupferu dzimtu no Kurzemes un ļoti daudzus citus. ${ }^{15}$

\title{
Bergmaņu dzimta
}

\author{
Uz vissmalkākajām nervu stīgām \\ Spēlmans savu dziesmu pauž; \\ Pirkstus gan tu jūti slīdam, \\ Pašu skaits tavs nenojauš!
}

K. L. ŠLEIHS ${ }^{16}$

Bergmaņi bija viena no izglītotākajām un ietekmīgākajām vācbaltiešu dzimtām, kas 18. un 19. gadsimtā ieviesa Apgaismības laikmeta idejas Latvijā un deva spēcīgus ierosmju impulsus latviešu zemnieku izglītības veicināšanai. Par dzimtas ciltstēvu uzskata Rīgas tirgotāju Palmu Bergmani (1672-1751). ${ }^{17}$ Viña dēls Baltazars Bergmanis (1703-1768) studēja medicīnu Jēnā un Vitenbergā, bet tad nolēma mācīties teoloǵiju Leipcigā, un kā teoloǵijas maǵistrs viņš atgriezās dzimtenē un bija luterāņu draudzes mācītājs Skujenes, vēlāk Bukultu (Neuermühlen) draudzē. Viņam bija četri dēli - Baltazars (1736-1789), Ambrozijs (1740-1784), Gustavs (1749-1814) un Liborijs (1754-1823).

Vecākais brālis Baltazars Bergmanis pēc tieslietu studijām Jēnas universitātē kḷuva par Vidzemes hoftiesas locekli, ierosināja izveidot biedrību apgaismības ideju izplatīšanai Vidzemē ar nolūku veicināt latviešu valodas mācīšanos vācbaltiešu vidē. Ambrozijs Bergmanis studēja medicīnu Strasbūrā un Leipcigā, kur 1762. gadā aizstāvēja doktora darbu "Par Vidzemes iedzīvotāju veselības un slimības stāvokli". ${ }^{18}$ Gustavs Bergmanis studēja teologiju un dabas zinības Leipcigas universitātē, bija luterāṇu mācītājs Āraišos, Mazsalacā un Rūjienā, kur savā mājā iekārtoja

15 Stradiņš J. Zinātnes un augstskolu sākotne Latvijā. - Rīga: Latvijas vēstures institūta apgāds, 2009.

16 K. L. Šleihs (1859-1922), ķirurga E. Bergmaņa asistents Berlīnē (1886).

17 Von Bergmann E. Des Palm Bergmann Nachkommen 1672-1886. - Riga, 1886.

18 "De stata sano et morboso incolarum Livoniae". 
grāmatu spiestuvi, 1807.-1808. gadā izdeva pirmos latviešu tautasdziesmu jeb "Latviešu epigrammu” (Lettische Sinngedichte) krājumus, organizēja Vidzemes iedzīvotāju vakcināciju pret bakām. Arī jaunākais brālis Liborijs Bergmanis studēja teolog̣iju Leipcigas universitātē, pēc filozofijas doktora grāda iegūšanas viņš ieguva Rīgas Sv. Pētera baznīcas draudzes mācītāja vietu, nodibināja Pilsoņu literāri praktisko biedrību, Vidzemes mākslas muzeju (1816), no jauna atklāja un pirmais izdeva Vecākās atskaņu hronikas fragmentus par Livonijas ordeņa vēsturi ar saviem komentāriem.

Gustava Bergmaņa dēls Ernsts Bergmanis ieguva labu vispārējo izglītību Bērzaines ǵimnāzijā pie Cēsīm (1851-1854), studēja medicīnu Tērbatas universitātē (1854-1860), kur pēc promocijas darba aizstāvēšanas strādāja par asistentu ķirurǵijas klīnikā, no 1871. gada - par profesoru Tērbatas universitātē. Par godu Tērbatas universitātes 75 gadu jubilejai viņam 1876. gadā lūdza nolasīt akadēmisko lekciju par modernajiem pētījumiem vēža izcelsmēe. ${ }^{19}$ 1877. gadā viņš kā kara ķirurgs piedalījās Krievijas-Turcijas karā Balkānos, kur lazaretēs sāka ieviest modernos brūču aseptikas principus. 1878. gadā viņš pieņēma piedāvājumu pārcelties strādāt uz Vircburgas universitāti, bet 1882. gadā - uz Berlīnes universitātes ķirurǵijas klīniku, kur konsekventi ieviesa operāciju veḷas sterilizāciju ar tvaiku un citus aseptikas principus. 1904. gadā viņš piedalījās vācu àrstu izglītības laikraksta "Zeitschrift für ärztliche Fortbildung” izveidē, kopā ar citiem autoriem uzrakstīja vairākas populāras ķirurǵijas mācību grāmatas.

Viņa Vircburgā dzimušais dēls Gustavs fon Bergmanis studēja medicīnu Berlīnes, Minhenes, Bonnas un Štrasburgas universitātē. Pēc tam viṇš līdz 1912. gadam strādāja Berlīnes universitātes 2. medicīnas klīnikā un tās vadītāja profesora Frīdriha Krausa (1858-1936) vadībā aizstāvēja habilitācijas darbu (1908). 1916. gadā viņu ievēlēja par Internās medicīnas katedras vadītāju Marburgas universitātē, bet 1920. gadā - par katedras vadītāju Frankfurtes pie Mainas universitātē. Viņa pētījumi par ķermeņa funkcionālajiem traucējumiem un veǵetatīvās nervu sistēmas ietekmi uz peptiskās čūlas slimības, žultsakmeņu slimības un primārās hipertensijas attīstību deva impulsu psihosomatologijas attīstībai Vācijā. 1922. gadā Gustavs fon Bergmanis universitātē nolasīja akadēmisko runu par dvēseles

19 "Die gegenwärtigen Forschungen über den Ursprung des Krebses". 
un ķermeṇa jēdzienu internajā medicīnā. ${ }^{20}$ 1927. gadā viṇš kḷuva par Berlīnes universitātes medicīnas fakultātes Charité profesoru. Mūža otrajā pusē viņš publicēja vairākas grāmatas par nepieciešamību medicīnā attīstīt jaunu domāšanas veidu, kas atzītu arī funkcionālās patologijas nozīmi un savienotu modernās fizikas priekštatus par cilvēka ķermeņa uzbūvi ar tradicionālo ārsta pasaules redzējumu. ${ }^{21,22,23}$ Viņu uzskata par vienu no vācu psihosomatiskās medicīnas skolas aizsācējiem. Vācu Internās medicīnas biedrības augstākais apbalvojums ir Gustava fon Bergmaņa medalı (Gustav von Bergmann Medaille).

Viņa uzskatos saskatāma nepārprotama līdzība ar latviešu medicīnas profesora Mārtiņa Zīles pārliecību. Vai šo līdzību nosaka tā laika vācu universitātēs izplatītie uzskati vai arī senākā Tērbatas universitātes zinātniskā skola, kuru savukārt ietekmējis viduslaiku Livonijas garīgais mantojums un Bergmaņu dzimtas tradīcijas?

\section{Mārtiṇa Zīles internās medicīnas skola}

Singulare sentitur, universale intelligetur. ${ }^{24}$

MĀRTIN̦Š ZīLE

Pēc Latvijas Augstskolas rektora Ernesta Felsberga aicinājuma Jaunkrievijas (Novorosijas) universitātes profesors Mārtiņš Zīle 1922. gada 21. februārī pārtrauca savu mācībspēka darbību Odesā un pārcēlās uz Rīgu, kur 11. aprīlī augstskolas zinātniskajā padomē tika ievēlēts par jaunizveidotās Medicīnas fakultātes “Terapeutikas" klīnikas profesoru. 30. aprīlī, pārņemot klīnikas vadību, viņš nolasīja iestājas runu "Par slimības klīnisko jēgumu. Kas ir slimība?”. Savas lekcijas sākumā viņš pauda uzskatu, ka

20 Von Bergmann G. Seele und Körper in der inneren Medizin. - Frankfurter Universitätsreden, XIV, 1922.

21 Von Bergmann G. Funktionelle Pathologie. Eine klinische Sammlung von Ergebnissen und Anschauungen einer Arbeitsrichtung. - Berlin: Verlag von Julius Springer, 1936.

22 Von Bergmann G. Das Weltbild des Arztes und die moderne Physik: ein Ausgleich alter Widersprüche. - Berlin: Springer-Verlag, 1943.

23 Von Bergmann G. Neues Denken in der Medizin. - München: Piper, 1947.

24 Tulkojumā no latīṇu val. "Atsevišķo sajūtam, vispārīgo izprātojam." 
Latvijas valsts liktenis un nākotne būs atkarīga no tās pilsoṇu miesīgās un garīgās darbaspējas, tāpēc medicīnai un ārstu darbībai ir uzlikta liela atbildība. Katra ārsta ideāls ir stingri individualizēta terapija, kas atkarīga no pareizas diagnozes. Tomēr vispirms ir jānoskaidro, kas ir slimība? Profesors Zīle pauda uzskatu, ka slimības pamatā ir korelācijas traucējums - vai nu hormonāls, vai neirāls, vai arī tīri mehānisks. Turklāt ārsta pienākums nebeidzas ar slimnieka dziedināšanu un ciešanu atvieglošanu, viņam ir arī jāmāca cilvēki, kā izsargāties no slimībām. ${ }^{25}$

Turpmākajos gados profesors M. Z̄̄le, lai gan bija sasniedzis gandrīz 60 gadu vecumu, ar gluži jauneklīgu enerǵiju uzņēmās arvien jaunus un jaunus pienākumus, vadot Latviešu ārstu biedrību (1923-1929) un LU Medicīnas fakultāti (1923-1925). 1925. gadā viņš vadīja 1. Latvijas ārstu un zobārstu kongresu, kura atklāšanas lekcija bija "Par slimību un higioǵenēzi. Korelācijas patoloğija un korelācijas terapija”. Tajā viņš izklāstīja savu jauno higioǵenēzes jeb "veselības stiprināšanas" teoriju, ka veselības pamatā ir korelācijas starp organisma šūnām, audu šķidrumiem un neirālo regulāciju atjaunošana. Pretstatā vairumam tā laika medicīnas zinātnieku, viņš noliedza, ka slimību cēloṇi meklējami vien̄̄gi šūnu patologiijā. Katrā šūnā, katras šūnas kodolā atsevišķās dalinnas funkcionāli savā starpā korelatīvi saistītas kā ķīmiski un mehāniski, tā arī neirāli (reflektoriski), tie paši korelatīvie faktori spēlē lomu arī šūnu, audu grupu un orgānu savstarpējās attiecībās. Orgānu un audu grupa savā kopumā - kā ķermenis - ir korelatīvi saistīta ar savu apkārtni, ar visumu. Visi notikumi mūsu organismā pakḷaujas savstarpējās partnerības principam. ${ }^{26}$

Šajos uzskatos pilnīgi noteikti ir atrodama saistība ar jau iepriekš pieminētā Hamburgas universitātes Vides pētīšanas institūta vadītāja Jakoba fon Ikšķila uzskatiem, ar kuru M. Zīle bija vienlaikus studējis Tērbatas universitātē. Par saviem domubiedriem, kurus viņš dēvēja par sintēzes virziena domāšanas piekritējiem, profesors Z̄̄le minēja ne tikai Jakobu fon Ikšksilu, bet arī Berlīnes universitātes medicīnas profesoru Frīdrihu Krausu (1858-1936), kas bija Gustava Bergmaņa habilitācijas

${ }^{25}$ Zīle M. Par slimības klīnisko jēgumu. Kas ir slimība? // Latvijas Ārstu Žurnāls, 1923; 1: 2.-8. lpp.

26 Zīle M. Slimība un higioǵenēze. Korelācijas patologiija un korelācijas terapija // 1. Latvijas ārstu un zobārstu kongresa darbi. - 1925, 23.-31. lpp. 
darba vadītājs Berlīnes universitātē. Vēl par saviem domubiedriem viņšs sauca arī Vīnes psihoterapeitu Alfrēdu Adleru, Tībingenes universitātes patologu Martinu Heidenhainu, Prāgas Kārḷa universitātes fizioloǵijas profesoru Armīnu Čermaku fon Zeizenegu (Tschermak Seysenegg), Cīrihes fiziologu Valteru Rūdolfu Hesu, Heidelbergas universitātes patologu Paulu Ernstu, Cīrihes neirologu Konstantīnu fon Monakovu (von Monakow), Grācas neiroloǵijas profesoru Frīdrihu Hartmani, Getingenes kara ārstu un rakstnieku Feliksu Buterzaku un Hamburgas Psihologijas institūta vadītāju Viljamu Šternu. ${ }^{27}$

1927. gadā profesoru Z̄ili ievēlēja par Latvijas Universitātes rektoru. Rektora pienākums bija arī akadēmiskās runas teikšana Latvijas Universitātes gadadienā. 1927. gada 28. septembrī viņš uzstājās ar priekšlasījumu "Kauzalitāte un finalitāte zinātnē un dzīvē". Ar šīs mācības palīdzību Mārtiņš Zīle tēlaini mēgināja formulēt pamatlikumus, kas valda pār cilvēka ķermeņa matēriju, un parādīt to lietošanas iespējas klīniskā domāšanā. Lai pietuvotos šai jaunajai izpratnei, viņš sev raksturīgā tēlainās domāšanas veidā cilvēka organismu salīdzina ar ēku, kuras stabilitāti un funkcionalitāti nosaka korelācijas mehānika un dinamika. Cilvēka organisms ir kā ēka, kas sastāv no pamata, pīlāriem, šķērskokiem un spārēm, arkām utt. Visas šīs atsevišksāa daļas nav patvaļīgi saliktas krustām šķērsām, bet gan tajās izpaužas sistēma, stils un jēga. Š̄̄s atsevišķās daḷas veido saskan̄̄gu veselumu, jo tās savietotas korelatīvi, t. i., savstarpējā atkarībā. Būves labums un izturība atkarīgi no tās korelācijas mehānisma jeb korelāciju maǵistrāḷu izveides. Laika gaitā būvei var veidoties defekti. Ēkas stūrī un sienā var izkustēties vairāki akmeņi vai arī vētras dēl jumtā var tikt bojāti vairāki kārniṇi. Ja korelācijas maǵistrāles nav strukturāli cietušas, ēkas stabilitāte vai tās stils vēl netiek izjaukti. Ēka stabili stāv, un to var viegli salabot. Ja tomēr ir bojāta kaut vai maza daḷa korelācijas maǵistrāḷu, iegrimst mazāka vai lielāka ēkas daḷa vai arī sabrūk visa celtne. Korelācijas maǵistrāḷu struktūras kvantitatīvs bojājums izraisa stila kvalitātes bojājumu vai arī visas būves pilnīgu iznīcināšanu, bet to nedara ēkas kvantitatīvs defekts, kas neskar korelācijas maǵistrāles. Tātad patiesas briesmas rada ne katrs ēkas bojājums par sevi, bet gan korelācijas mehānisma maǵistrāḷu bojājums.

27 Zīle M. Par ārsta pasaules skatīijumu un slimības jēgu. - Rīga: Medicīnas apgāds, 2011. 
Interesantā veidā šo tēlaino salīizinājumu viṇa skolnieks Kristaps Rudzītis vēlāk attīstīja teorijā par dentālo infekciju ("caura mājas jumta") ietekmi uz visa organisma hronisko slimību attīstību, bet šajā laikā Kristaps Rudzītis pēc Mārtiņa Zīles ierosmes turpināja viṇa Odesā sāktos patofiziologískos pētījumus par neirālās stimulācijas ietekmi uz iekšējo orgānu sekrēciju. 1928. un 1929. gadā žurnālā "Wiener klinische Wochenschrift" tika publicēta triju rakstu sērija par gāzveidīgo un tvaikveidīgo vielu ietekmi uz cilvēka organismu. ${ }^{28}$

1929. gadā Mārtiņš Zīle, sasniedzis karjeras virsotni, atstāja gandrīz visus administratīvos amatus Latvijā, izņemot fakultātes Terapijas klīnikas vadīšanu, un starptautiskā mērogā pilnībā nodevās savu filozofisko uzskatu sludināšanai, kas vainagojās ar vairākiem kongresiem medicīniskās sintēzes veicināšanai Rīgā un Marienbādē (Čehoslovākijā) un trīs apjomīgām monogrāfijām. 1930. gada kongresā, kas notika Latvijas Universitātes aulā Rīgā, medicīniskās sintēzes veicināšanai viņš nolasīja lekciju ar nosaukumu "Priekšvārds pie vispārīgās klīniskās mācības par slimību". Viņš postulēja, ka sakārtota dzīvības norise ķermenī var notikt vienīgi tad, ja katrā veǵetatīvā funkcionālā vienībā (vācu val. vegetatives Betriebsstück) ir trīs korelatīvi faktori:

1) funkcionēt spējīga vienība, proti, šūna;

2) izejmateriāls, proti, asinis un audu šksidrums;

3) direkcija jeb vadība, kas, no vienas puses, nosaka šūnas darbu, un, no otras, tam atbilstoši rūpējas par nepieciešamo izejmateriālu, kas ir šūnas un asinsvadu inervācija.

Ja organisms ir vesels, trīs faktori ir funkcijas ziņā optimāli ieregulēti cits pret citu. Ja viens vai otrs no tiem ir uz augšu vai uz apakšu no optimālās korelācijas līnijas, sākas patolog̣iska norise, kas noved līdz izteiktām, vairāk vai mazāk ilgstošām morfologisiskām pārmaiņām.

M. Zīle ar savas teorijas par veǵetatīvo funkcionālo vienību palīdzību mēǵina izskaidrot spontāno un mākslīgi izraisīto higioǵenēzi (atveseḷošanos). Veğetatīvās funkcionālās vienības patologisko korelācijas dinamiku bieži var labot ar audu šksidruma plūsmas pārmaiņām, t. i., ar aktīvas hiperēmijas un hiperlimfēmijas palīdzību. Ar to tiek atjaunots

28 Rudsit K., Sihle M. Untersuchungen über den Einfluß einiger gas- und dampfförmiger Mittel auf den menschlichen Organismus // Wiener klinische Wochenschrift, 1928; 10: S. 333-337. 
no normas izgājušais un audu darbībai nepieciešamais turgors. Optimāls turgors nodrošina optimālu audu elastību, kas nepieciešama orgānu optimālai funkcijai, proti, veselībai. M. Z̄̄le izsaka domu, ka veselība atkarīga no audu turgora kvalitātes un kvantitātes. Vairumam cilvēku nehigiēniska dzīvesveida dēl audu turgors veǵetatīvā funkcionālajā vienībā ne tuvu nav optimāls gan kvalitātes, gan kvantitātes aspektā, tādēl cieš šūnu un šūnu grupu savstarpējais sinerǵisms un partnerība, proti, produktīvais darbs. Šajā sakarībā kḷūst saprotama asins nolaišanas nozīme, kas kādreiz tika daudz lietota. Tāpat kā citur, arī šeit pēkšņais grūdiens, ko izraisa intensīvas pārmaiņas veǵetatīvajā funkcionālajā vienībā, ir viens no iemesliem, kādēḷ ar šīs korelācijas dinamikas pārmaiņu palīdzību notiek audu turgora kvantitatīvas pārmaiṇas un uzlabošanās un arī slimīgā stāvokḷa uzlabošanās. Dažādu patoloǵisku stāvokḷu un arī novecošanas dēḷ vērojama pastiprināta nogulšņu veidošanās audu un šūnu šķidrumā. Pastiprinātu nogulšņu veidošanos audos atrod visos iespējamos artrīta veidu gadījumos, vai tie ir infekciozi vai toksiski, arteriosklerozes, aptaukošanās, diabēta gadījumā utt. Terapeitiski šos slimību stāvokḷus daudzveidīgi un sekmīgi var ietekmēt ar dūñu un sāls peldēm, diatermiju, saules peldēm un citādi. Visu šo procedūru gadījumos galvenais faktors ir audu turgora palielināšana.

Viņa mācību par saistaudu sistēmas lomu slimības izcelsmē attīstīja Kristaps Rudzītis, kas 1932. gadā aizstāvēja disertāciju "Klīniski un kolō̄dķīmiski pētījumi par paradoksām reakcijām” un vēlāk radīja pats savu mācību par heparīnu saturošo šūnu nozīmi audu iekaisumreakciju regulēšanā.

Vai ir izsekojama arī citu Mārtiņa Zīles ideju ietekme uz Latvijas internās medicīnas zinātnisko skolu?

\section{Mārtiṇa Zīles ideju mantinieki}

Klīniskais skolotājs, kas izplata pareizas vai nepareizas mācības, ir vēl vairāk atbildīgs par slimnieka likteni

kā ārsts, kas dod slimniekam padomu.

MĀRTIN̦Š ZĪLE (1922)

Profesora Zīles idejas tiešā un netiešā veidā ietekmējušas daudzus Latvijas patologus un internistus. Par viņa galvenajiem zinātniskajiem sekotājiem patolog̣iskās anatomijas jomā jāuzskata patologs Romāns Adelheims (1881-1938), bet internās medicīnas jomā - profesors Kristaps Rudzītis 
(1899-1978) un viņa skolēni Rūdolfs Feldmanis (1904-1970), Nikolajs Skuja (1913-2012), Valentīns Būmeisters (1914-1987), Gaida Liepiṇa (1914-2005), Agnis Štifts (1923), Nikolajs Andrejevs (1930-2002), Gaitis Brežinskis (1931-1988) un, protams, Ilmārs Lazovskis (1931-2003). Vistiešākā uzskatu pēctecība vērojama Latvijas Universitātes, kopš 1950. gada - Rīgas Medicīnas institūta - Terapijas katedras mācībspēku uzskatos.

Piemēram, šādi Mārtiņa Zīles izteikumi atspoguḷojās viņa sekotāju nostājā:

"Slimība ir saskaņas jeb korelācijas trūkums starp dzīvības energiju uzturošajiem antagonistiem, piemēram, starp simpātisko un parasimpātisko nervu sistēmu.

Ārsta uzdevums ir dot slimnieka dzīvības procesiem tādu grūdienu jeb pavilkt tos reǵistrus (ar medikamentiem, fizikālo terapiju u. c.), lai katram cilvēkam piemītošie potenciālie dziednieciskie faktori spētu nodrošināt tālāko izveselıošanās procesu." 29

Šeit redzama nepārprotama līdzība ar Kristapa Rudzīša rakstīto:

"Slimību diagnosticēt nozīmē ne vien to atpazìt, bet arī pareizi novērtēt tās cēloņus, pareizi raksturot slimā organisma patologiskās norises tā, lai tas dotu iespēju noteikt slimības ārstēšanu un paredzēt tās tālāko gaitu.

Ārstam jāārstē nevis slimība, bet gan slimais cilvēks.

Cilvēka organisms ir arī vienots sevī. Tas nosaka, ka atbildes uz dažāda veida ārējām ietekmēm dod viss organisms, pie kam katrā gadījumā piedalās komplicēta orgānu korelāciju sistēma:

1) anatomiski strukturālās un topogrāfiskās korelācijas;

2) hormonālās korelācijas;

3) neiroreflektoriskās korelācijas un

4) asinsrites korelācijas.

Faktori, kas piedalās cilvēka fizioloǵisko un patofizioloǵisko norišu mehānismā, var būt gan mikroskopiski un ultravizibli, gan planetāri un galaktiski." 30

29 Sihle M. Über das Weltbild des Arztes und den Sinn der Krankheit. Ein Apell zur Lebenssynthese. - Wien, Leipzig, Bern, 1934.

30 Rudzītis K. Diagnostikas pamati un terapijas preambula. - Rīga, 1972. - 275 lpp. 
Mārtiņa Zīles un Kristapa Rudzīša ietekmi var sajust arī Valentīna Būmeistera uzskatos. Savā apcerējumā par Stradiņa slimīcas Iekšķ̄īgo slimību klīnikas ārstiem profesors I. Lazovskis rakstīja:

"Pāri visam V. Būmeisters lika slimību cēloṇus un mehānismus. Docenta uzmanību aizvien piesaistīja cēloṇi, kas varētu būt kopīgi daudzām slimībām un ietekmēt dažādu slimību norisi. Ja cilvēkam bieži sāp galva, ja viņš ir pārlieku noguris un nervozs, viņam ir paaugstināts asinsspiediens, tā visa cēlonis var būt meklējams mutē: zobārsts ir apvilcis vairākus zobus ar dažādiem metāliem - zeltu un sudrabu vai nerūsējošo tēraudu. Elektriskā strāva starp šiem metāliem var būt par minēto un citu kaišu cēloni." 31

Profesors Ilmārs Lazovskis bija Kristapa Rudzīša pēctecis Terapijas katedras vadītāja amatā. Viņš pirmais "Acta medico-historica Rigensia" 1994. gada izdevumā rakstīja par Mārtiņa Zīles internās medicīnas skolu. ${ }^{32}$ Mārtiņa Zīles ideju ietekme uz Ilmāra Lazovska uzskatiem vislabāk ir redzama viņa 1995. gadā publicētajā filozofiskajā rakstā "Haosa teorija un fenomenologiska pieeja pacientam":

"Modernā medicīna balstās teorijās un pieņēmumos, kas atvasināti galvenokārt no lineāru sakarību pētījumos iegūtiem rezultātiem. Tomēr medicīnas praksē ārsti izjūt dzīves dažādību un sarežğîî̄bu un bieži vien jūtas iestrēguši izmeklējumu datos, mēǵinot tos sagrupēt logiskā diagnostiskā vai terapeitiskā secībā. Dzīvības procesi nav tikai cēloṇi un sekas, dzīve ir iespējas un apstākḷi, daudznozīmība un nestabilitāte. Modernās dabaszinātnes piedāvā dabas parād̄̄bu izpēti no haosa teorijas viedokḷa, īpaši izcel̦ot daudzu procesu neparedzamību, adaptāciju kompleksumam, nestabilitāti un variācijas.

Simetrija šaurākā nozīmēe ir viena no idejām, ar kuras palīdzību cilvēks gadu tūkstošiem mēǵināja saprast un radīt kārtību, skaistumu un pilnību sev apkārt. Simetriskuma tieša antitēze ir haoss jeb galīgs apjukuma stāvoklis. Uz haosa sliekšņa klasiskā zinātne apmulst un

${ }^{31}$ Lazovskis I. Iekšķīgo slimību klīnikas // Stradiņa slimnīca. Rakstu vainags deviņdesmitgadē. - Rīga, 2000. - 96.-107. lpp.

32 Lazovskis I. Martin Sihles Schule der inneren Medizin in Lettland // Acta medico-historica Rigensia. - Vol. II (XXI). - 1994. - 169.-183. lpp. 
apstājas, neraugoties uz vismodernākajām pētīšanas metodēm. Katrā dabas parādībā, norisē vai priekšmetā ir it kā iekšējas robežas, kas neḷauj paredzēt nākotni visos tās sarežǵgitīibas līmeņos. Veselība kā haotiska sistēma katrā savā norisē nepārtraukti zaudē līdzvaru un nepārtraukti atgriežas tajā. Tad kḷūst saprotams, kādẹl vairums slimību beidzas ar izārstēšanos pat bez jebkādas iejaukšanās jeb ārstēšanas. Tomēr dažām slimības formām iznākums ir nelabvēlīgs, jo izveidojies fiksēts atraktors, kas sistēmai neļauj atgriezties līdzsvara stāvoklī. Ar daudzu diagnostisku izmeklējumu palīdzību mēs mēǵinām noteikt to, cik lielā mērā organisma haotiskā sistēma ir izsista no līdzsvara un paredzēt slimības tālāko norisi. Tā kā norises organismā ir haotiskas, to paredzamība ir aptuvena, un tā prasa adaptāciju kompleksumam kā no slimnieka, tā arī no ārsta puses." 33

\section{Kopsavilkums}

Latvijas medicīnas tradīcijas jau kopš viduslaikiem veidojušās mijiedarbībā starp tautas dziedniecību ar tai raksturīgo holistisko pasaules uztveri un mūku ordeņu klosteru medicīnu, ko pēc baznīcas reformācijas, vismaz Rīgā, aizstāja akadēmiski izglītotie pilsētas ārsti. Dažādu tautu kultūru mijiedarbībā vismaz septiņu gadsimtu laikā Baltijas zemēs izveidojās īpaša mentalitāte, kas izpaudās arī vietējās medicīnas tradīcijās un uzskatos par slimību un veselību.

Latvijas internās medicīnas zinātniskā skola ir izveidojusies stiprā Tērbatas universitātes medicīnas zinātniskās skolas ietekmē, un to vairāku paaudžu ilgumā ietekmējuši ne tikai universitātes medicīnas profesori, bet arī filozofijas un dabaszinātņu profesori. Līdzīgu Tērbatas universitātes medicīnas zinātniskās skolas ietekmi var atrast arī uz 20. gadsimtā Vācijas universitātēs strādājošajiem vācbaltiešu izcelsmes zinātniekiem. Latvijas internās medicīnas skolas dibinātājs un pamatideju autors bija Latvijas Universitātes Medicīnas fakultātes Terapijas klīnikas vadītājs, profesors Mārtiņš Zīle, kura idejas tālāk attīstīja viņa pēcteči, profesori Kristaps Rudzītis un Ilmārs Lazovskis.

33 Lazovskis I. Haosa teorija un fenomenologiska pieeja pacientam // LZA Vēstis, A. sērija, 1995; 3/4: 57.-65. lpp. 
Latvijas internās medicīnas skolas vispārīgās pazīmes ir integrēta pieeja pacientam kā indivīdam un interese par visu slimību kopumu, kas ietver holistisku pacienta izmeklēšanu un vides faktoru ietekmes noskaidrošanu. Papildu pazīme ir interese par medicīnas terminoloǵiju un plašs interešu loks ārpus medicīnas (mūzika, filozofija, glezniecība, vēsture, dzeja, valodniecība). Mārtiņa Zīles un viṇa sekotāju idejas ir ietekmējušas arī psihosomatiskās medicīnas attīstību Latvijā.

\section{The Latvian School of Internal Medicine as a Model for Succession of Ideas}

\section{Abstract}

Medical traditions in Latvia have, since the Middle Ages, been organised with interaction between folk medicine and its characteristically holistic perceptions of the world on the one hand, and the medicine of cloisters of monks that was replaced after the Reformation, at least in Rìga, by academically educated city physicians. Because of the interaction of the cultures of many different nationalities, a special mentality emerged in the Baltic region over the course of at least 700 years, and it is seen in local medical traditions and views about sickness and health.

The scientific school of internal medicine in Latvia emerged under the strong influence of the School of Medicine at Tartu University, and for many generations it has been influenced not just by medical professors, but also by philosophy and natural science professors. Similar to the influence of the School of Medicine at Tartu University was the influence of Baltic German scholars who worked for German universities in the $20^{\text {th }}$ century. The founder of the school of internal medicine in Latvia was Professor Mārtiņš Zīle, who chaired the Faculty of Medical Therapy at the University of Latvia for many years. His ideas were later developed further by Professor Kristaps Rudzītis and Professor Ilmārs Lazovskis.

Latvia's school of internal medicine is characterised by an integrated approach toward each patient as an individual, as well as by an interest in the whole world of disease. This includes holistic examinations of patients, as well as an identification of environmental factors that influence 
people's health. There is also an interest in medical terminology, and there is a wide range of interests outside of medicine as such (music, philosophy, painting, poetry, linguistics). The ideas of Mārtiņš Zīle and his successors have also influenced the development of psychosomatic medicine in Latvia.

Valdis Pīrāgs, Dr. med., profesors

Latvijas Universitāte

pirags@1atnet.lv 